\title{
DIAGNOSIS AND CORRECTION OF SOIL NUTRIENT LIMITATIONS IN INTENSIVELY MANAGED SOUTHERN PINE FORESTS
}

Quarterly Report for the Period July-September 1999

N.B. Comerford

University of Florida

Date Published - October 1999

PREPARED FOR THE UNITED STATES

DEPARTMENT OF ENERGY

Under Cooperative Agreement

No. DE - FC36 - 99 GO10415 


\section{DISCLAIMER}

This report was prepared as an account of work sponsored by an agency of the United States Government. Neither the United States Government nor any agency thereof, nor any of their employees, make any warranty, express or implied, or assumes any legal liability or responsibility for the accuracy, completeness, or usefulness of any information, apparatus, product, or process disclosed, or represents that its use would not infringe privately owned rights. Reference herein to any specific commercial product, process, or service by trade name, trademark, manufacturer, or otherwise does not necessarily constitute or imply its endorsement, recommendation, or favoring by the United States Government or any agency thereof. The views and opinions of authors expressed herein do not necessarily state or reflect those of the United States Government or any agency thereof. 


\section{DISCLAIMER}

Portions of this document may be illegible in electronic image products. Images are produced from the best available original document. 


\section{Summary of Project Status And Activities Performed During the Quarter}

1. The development of model coding has continued. The features added during the past 3 months are:

a. Changing soil water content with time based on a external data set.

b. Flexibility in defining root growth during the defined time based on an external data set.

c. Incorporation of mineralization for each time step based on an external data set.

2. The model has two main parts. The nutrient demand part of the model was developed during the past 3 months. This involves reading biomass accumulation with time along with a nutrient use efficiency to define the nutrient demand. A data base for this part of the model was begun using existing data in the literature. The model is about $85 \%$ done.

3. Laboratory studies on the desorption of $P$ from a Florida soil were continued in order to determine how to most properly define the adsorption and desorption reactions in the model associated with both fertilization and absorption. We have found that for a spodic horizon we can predict the partition coefficient $(\mathrm{Kd})$ from a simple equation regardless of where on the adsorption isotherm we begin. It remains to be seen if this is true for other soil samples. We have also found that re-adsorption after the initial adsorption tends to follow the desorption curve than the original adsorption curve. We still need to determine how we will incorporate these data into the model. This is about $20 \%$ done.

4. We have begun similar studies as described in 3 for potassium. (This is about $5 \%$ done)

5. We have hired the post-doc and biologist early in order to start the field sampling and take advantage of an existing students $\mathrm{PhD}$ project. We have done initial sampling in order to work out the sampling protocol and are currently finalizing the sites belonging to International Paper Co. which we will use in this study. (This is just beginning)

6. Sensitivity Analysis for $\mathrm{NO}_{3}, \mathrm{~K}$ and $\mathrm{PO}_{4}$ have been run on the current form of the model. Several coding errors were identified through these analysis and these coding errors have been corrected. This is $100 \%$ done.

7. A literature search was begun on the root to shoot relationships of fast growing pine in order to assist our development of the nutrient demand section of the model. This is about $1 \%$ done. 


\section{An Account of Percentage Completion of each task}

$\underline{\text { Task }}$

1. Development of Model

2. Error testing of model

3. Field measurement of study sites

4. Laboratory characterization of soils

5. Laboratory analysis of study site samples

6. Specific laboratory studies on soil processes
$\%$ Completed

$85 \%$

$85 \%$

$1 \%$

$0 \%$

$0 \%$

$20 \%$

\section{Variances to Cost or Project Schedule}

We have hired a post-doc and biological scientist. We expect to overspend our budget for this year. We wrote a letter on 20 July 1999 to Dr. James McDermott asking permission to overspend this year with the overspending being made up in next years budget. The university will allow this with written permission to that effect. At the time of this writing, we have not received written confirmation of that approval. There also seems to be some discrepancy about the budget for year 1. The UF grant's office has been trying to contact DOE personnel to get a definitive answer on this question, but it has been difficult for both parties to connect.

\section{Significant Accomplishments Expected in Next Quarter}

1. We expect to have $100 \%$ of the model complete and delivered at the end of the year.

2. We expect to check the results of the $P$ study on other soils of wide ranging characteristics to see how universal is the pattern we have seen to date.

3. We expect to have samples 2 to 3 sites in the field and begun work on plant and soil samples in the laboratory.

4. We expect to have initial literature values on fast growing southern pine collected and in a form to use in the model in order to help interpret our field data. 